\title{
Implementasi Kinerja Perangkat Desa Dalam Penyelenggaraan Pemerintah Desa Berdasarkan Undang-undang Nomor 6 Tahun 2014 Tentang Desa
}

\author{
Muliadin', Maemunah², Candra ${ }^{3}$ \\ ${ }^{1}$ Pendidikan Pancasila dan Kewarganegaraan FKIP Universitas Muhammadiyah Mataram, muliadin45@gmail.com \\ ${ }^{2}$ Pendidikan Pancasila dan Kewarganegaraan, Universitas Muhammadiyah Mataram, maemunahabdullah@gmail.com \\ ${ }^{3}$ Pendidikan Pancasila dan Kewarganegaraan, Universitas Muhammadiyah Mataram, candra5@gmail.com
}

\section{INFO ARTIKEL}

Riwayat Artikel:

Diterima: 21 Agustus

2017

Disetujui: 30 September 2017

\section{Kata Kunci:}

kinerja

perangkat

desa

pemerintah

desa

\section{ABSTRAK}

\begin{abstract}
Abstrak: Tujuan penelitian ini yaitu 1) Untuk mengetahui kinerja perangkat desa dalam penyelenggaraan pemerintah desa berdasarkan Undang-Undang Nomor 6 Tahun 2014 Tentang Desa, 2) Untuk mengetahui kendala-kendala tentang kinerja perangkat desa dalam penyelenggaraan pemerintah di Desa Gunung Sari Kecamatan Gunung Sari Kabupaten Lombok Barat Tahun 2017. Metode penelitian yang digunakan menggunakan hukum empiric dengan pendekatan normatif yuridis.Pengumpulan data dipakai adalah observasi, wawancara dan dokumen kemudian analisis data menggunakan penyajian data, reduksi data dan kesimpulan. Hasil penelitian ini menunjukkan bahwa 1). Kinerja perangkat desa dalam penyelenggaraan pemerintah desa berdasarkan Undang-Undang Nomor 6 Tahun 2014 Tentang Desa sudah berjalan secara optimal, hal tersebut terlihat dari kemampuan Dalam Membuat Perencanaan Pembangunan Desa, kemampuan Dalam Memberikan Pengarahan Kepada Bawahan atau Masyarakat Dalam Pelaksanaan Pembangunan, dan kemampuan Dalam Mengambil Keputusan Dalam Proses Penyelenggaraan Pembangunan, 2) Kendala-kendala tentang kinerja perangkat desa dalam penyelenggaraan pemerintah di Desa Gunung Sari Kecamatan Gunung Sari Kabupaten Lombok Barat Tahun 2017 yaitu a) Persoalan Sumber Daya Manusia b) Fenomena pengalaman sistem pembangunan dari masa orde baru hingga masa reformasi saat ini masih kuat di memori masyarakat desa.
\end{abstract}

\begin{abstract}
The purpose of this study is 1) To determine the performance of village officials in the implementation of village government based on Law Number 6 of 2014 concerning Villages, 2) To find out the constraints about the performance of village officials in the administration of the village in Desa Gunung Sari Kecamatan Gunung Sari Kabupaten West Lombok on the year 2017. The research method used uses empirical law with a normative juridical approach. Data collection used is observation, interviews, and documents, and the data analysis using data presentation, data reduction, and conclusions. The results of this study indicate that 1). The performance of the village apparatus in the implementation of the village government based on Law Number 6 of 2014 concerning the Village has been running optimally, it can be seen from the ability to make village development planning, the ability to provide direction to subordinates or communities in implementing development, and the ability to make decisions In the Process of Organizing Development, 2) Constraints about the performance of village officials in the administration of Desa Gunung Sari Kecamatan Gunung Sari Kabupaten West Lombok in 2017, namely a) Human Resource Issues b) Phenomenon of development system experience from the New Order era to the reform era when this is still strong in the memory of the village community.
\end{abstract}

\section{A. LATAR BELAKANG}

Kelahiran Undang-Undang Nomor 6 tahun 2014 tentang Desa disambut semarak, tidak terbatas oleh pemerintah desa. Undang-Undang desa menjadi topik perbincangan di berbagai diskusi publik, media, maupun keseharian warga. Optimisme tumbuh meski tidak semua pihak menatap Undang-Undang desa dengan pemahaman yang sama. Sebagian melihatnya sebagai tonggak dimulainya pendalaman demokrasi pada aras lokal, lainnya menganggap Undang-Undang desa sebagai jalan membangun kemandi-rian desa dan ekonomi warga.

Penyelenggaraan Pemerintahan Desa yang memasuki babak baru ini diiringi dengan diterbitkannya Undang-Undang Nomor 6 tahun 2014 tentang Desa ini, jika kita tahu bahwa sepanjang era reformasi, pengaturan mengenai desa masuk dalam UndangUndang Pemerintahan Daerah Nomor 22 tahun 1999, kemudian diubah menjadi Undang-Undang Nomor 32 tahun 2004. Jika pada mulanya arah reformasi mendorong pengakuan desa dengan mengembalikan 
kemandirian lokal (desentralisasi), namun dalam perkem-bangannya justru bergeser ke arah corak resentrelisasi.

Undang-undang desa ini dinilai penting, setidaknya karena 2 (dua) alasan, Pertama, melalui UndangUndang desa diharapkan terbentuk basis legalpengaturan yang jelas dan spesifik memgenai desa, karena sejak reformasi pengaturan desa masih menginduk dalam Undang-Undang Pemerintahan Daerah. Padahal kompleksitas desa membutuhkan sistem penanganan tersendiri. Kedua, melalui Undang-Undang desa ini, diharapkan ada terobosan baru terwujudnya pembaharuan desa ke arah demokratisasi, kemandirian, dan kesejahteraan. Setidaknya dalam Undang-Undang desa ini terkandung harapan besar sekaligus pertaruhan masa depan rakyat desa.

Merujuk pada pasal 23 [1], maka dapat diketahui bahwa dalam penyelenggaraan pemerintahan desa ada 2 (dua) unsur pemerintahan penting yang berperan di dalamnya, yaitu Pemerintah Desa dan Badan Permusyawaratan Desa (BPD). Tugas utama yang harus diemban pemerintah desa adalah bagaimana menciptakan kehidupan demokratik, memberikan pelayanan sosial yang baik sehingga membawa masyarakatnya pada kehidupan yang sejahtera, rasa tentram, dan berkeadilan. Pemerintah desa dituntut untuk lebih memahami apa yang menjadi kebutuhan masyarakatnya. Itu juga berarti bahwa tata pemerintahan dan proses pembuatan kebijakan dan kebijakan yang dihasilkan menyangkut masalah bersama harus dapat diakses serta mampu dipertanggungjawabkan kepada publik.

Pada era reformasi diterbitkannya Undang-Undang Nomor 2 tahun 1999 kemudian disempurnakan menjadi [2] hingga saat ini dengan diterbitkannya [1] yang mana menegaskan dengan memberikan keleluasaan kepada desa untuk dapat lebih mengatur rumah tangganya sendiri sesuai dengan kondisi adat dan budaya setempat. Dalam Undang-Undang tersebut selanjutnya dipertegas dalam [3] yang memuat tentang pelaksanaan UndangUndang tentang Desa tersebut. Dari kewenangan yang dimiliki oleh desa tersebut diharapkan dalam pelaksanaannya sesuai dengan tujuan, yaitu mewujudkan otonomi desa dimana desa dapat mandiri dalam mengurus rumah tangganya sendiri [4].

Sehingga dalam konteks Undang-Undang otonomi daerah pada dasarnya telah memberikan peluang kepada desa untuk mengatur peyelenggaraan pemerintahan desa. Hanya saja dalam pasal 208 [2] menyebutkan bahwa tugas dan kewajiban kepala desa dalam memimpin penyelenggaraan pemerintahan desa diatur lebih lanjut dengan peraturan daerah dengan berdasarkan Peraturan Pemerintah.

Lahirnya [1] telah membawa perubahan mendasar bagi kedudukan dan relasi desa dengan daerah dan pemerintah baik dari aspek kewenangan, perencanaan pembangunan, keuangan dan demokrasi desa. Kedudukan desa dalam Undang-Undang desa kini lebih kuat. Asas subsidiaritas dan rekognisi yang dijelaskan pada pasal 3 menegaskan bahwa pemerintah mengakui dan menjamin adanya kewenangan bersifat asal-usul dan berskala desa. Pasal 5 lebih lanjut menegaskan desa berkedudukan di kabupaten/kota. [5] menyatakan bahwa "Desa dan Desa Adat mendapat perlakuan yang sama dari pemerintah dan pemerintah daerah". Implikasinya, desa secara politik bukan sekedar "bagian dari daerah", dimana sebelumnya hanya menerima "sisanya sisa" kewenangan dan keuangan daerah [6].

Dalam pasal 18 [1] dijelaskan bahwa cakupan kewenagan desa adalah penyelenggaraan pemerintahan desa, pelaksanaan pembangunan desa, pembinaan kemasyarakatan desa, dan pemberdayaan masyarakat desa berdasarkan prakarsa masyarakat, hak asal-usul, dan adat istiadat desa.

Aspek utama dalam pembangunan desa adalah perbaikan jalan raya. Ada beberapa titik kerusakan jalan di Desa Gunung sari. Pembangunan infrastuktur untuk menopang perekonomian masyarakat, serta pemanfaatan anggaran dana desa baik bantuan dari provinsi maupun pusat. Oleh karena itu, perangkat desa harus dapat bekerja efektif dan transparan guna meningkatkan pelaksanaan pembangunan desa. Selain itu, pembinaan kemasyarakatann desa sangat diperlukan. Masyarakat sangat antusias menyambut setiap ada kegiatan yang dapat memberdayakan potensi yang ada di daerah. Persoalan hanya terletak kepada bagaimana upaya yang dilakukan oleh kepala desa untuk merangkul tokohtokoh masyarakat dalam menggerakkan mereka karena maju tidaknya pembangunan di desa kami sangat bergantung kepada kepemimpinan pemerintah desa atau kepala desa. Selain itu, program pemberdayaan masyarakat desa juga sangat penting. Program ini berupa proses pembangunan dimana masyarakat desa berinisiatif untuk memulai proses kegiatan sosial untuk memperbaiki situasi dan kondisi diri sendiri. Pemberdayaan masyarakat desa hanya bisa terjadi apabila warganya ikut berpartisipasi.

\section{B. METODE PENELITIAN}

\section{Metode yang Digunakan}

Metode yang digunakan adalah kualitatif. Metode penelitian kualitatif adalah suatu metode penelitian yang mendeskripsikan masalah peneliti dengan menggunakan kalimat [7]. Selanjutnya metode kualitatif yaitu suatu metode yang menggambarkan keadaan atau peristiwa yang ada pada sakarang dengan cara mengumpulkan data dengan menggunakan kalimat [8].

Berdasarkan pendapat ahli di atas, maka metode penelitian yang digunakan adalah metode penelitian kualitatif dengan pendekatan deskriptif tentang implemen-tasi kinerja perangkat desa dalam penyelenggaraan pemerintah desa berdasarkan UndangUndang Nomor 6 Tahun 2014 Tentang Desa. 


\section{Subjek Penelitian}

Subjek penelitian adalah sekumpulan kasus yang perlu memenuhi syarat-syarat tertentu yang berkaitan dengan masalah penelitian [9]. Ahli lain mengemukakan bahwa subjek penelitian adalah sejumlah kasus yang yang akan diteliti [10]. Berdasarkan pendapat para ahli, maka yang dimaksud dengan subjek penelitian adalah sejumlah kasus yang akan diteliti.

Dalam penelitian kualitatif, populasi diartikan sebagai wilayah generalisasi yang terdiri atas: obyek/subyek yang mempunyai kualitas dan karakteristik tertentu yang ditetapkan oleh peneliti untuk dipelajari dan kemudian ditarik kesimpulannya. Sedangkan sampel adalah sebagian dari populasi itu. Dalam penelitian kualitatif tidak menggunakan istilah populasi, tetapi dinamakan social situation atau situasi sosial yang terdiri dari tiga elemen yaitu tempat, pelaku, dan aktivitas yang berinteraksi secara sinergi. Situasi sosial tersebut dapat dinyatakan sebagai obyek penelitian yang ingin diketahui di dalamnya. Pada situasi sosial atau obyek penelitian ini peneliti dapat mengamati secara mendalam aktivitas orang-orang yang ada pada tempat tertentu [7].

Dalam penelitian kualitatif, teknik sampling yang sering digunakan adalah Purposive sampling adalah pemilihan sampling penelitian dengan pertimbangan dan tujuan tertentu [7] Berdasarkan penjelasan tersebut, peneliti menggunakan teknik dalam pengambilan penelitian menggunkana Purposive sampling yaitu teknik sampling berdasarkan pertimbangan dan tujuan tertentu. Adapun subjek dalam penelitian ini adalah Kepala Desa, Staf Desa Gunung Sari Kecamatan Gunung Sari Kabupaten Lombok Barat dan masyarakat Gunung Sari.

\section{Teknik Pengumpulan Data}

Adapun jenis data yang digunakan dalam penelitin ini adalah data kualitatif yang berbentuk kalimat. Sedangkan data kuantitatif dalam penelitian ini yaitu data berbentuk angka tentang tentang kinerja perangkat desa dalam penyelenggaraan pemerintah desa berdasarkan Undang-Undang Nomor 6 Tahun 2014 Tentang Desa.

Sumber data dalam penelitian ini adalah sumber yang diperoleh dari subyek selama melakukan penelitian. Menurut [11], sumber data menurut sifatnya digolongkan menjadi 2 (dua) jenis yaitu sumber data primer dan sumber data sekunder.

1. Sumber data primer adalah sumber-sumber yang memberikan data lansung dari tangan pertama.

2. Sumber data sekunder adalah sumber mengutip dari sumber lain mencakup dokumen-dokumen resmi, buku-buku, hasil-hasil penelitian yang berwujud laporan.

Data primer yang digunakan dalam penelitian ini adalah data yang diperoleh dari hasil wawancara dan observasi tentang kinerja perangkat desa dalam penyelenggaraan pemerintah desa berdasarkan UndangUndang Nomor 6 Tahun 2014 Tentang Desa. Data sekunder yang digunakan dalam penelitian ini adalah data yang diperoleh dari hasil penelitian.

\section{Teknik Pengumpulan Data}

Teknik pengumpulan data adalah cara yang digunakan oleh peneliti untuk mengumpulkan data, dalam hal ini adalah proses diperolehnya data dari sumber data, sumber data yang dimaksud berasal dari subjek penelitian [12]. Dalam penelitian ini, data yang dikumpulkan menggunakan metode sebagai berikut:

\section{1) Metode Observasi}

Observasi adalah pengamatan kepada tingkah laku pada suatu situasi tertentu [13]. Pendapat lain mengemukakan bahwa observasi adalah alat untuk mengumpulkan data berupa tingkah laku tertentu [10]. Selanjutnya [13], jenis-jenis observasi meliputi observasi partisipatif, yaitu apabila pengobservasi ikut terlibat dalam kegiatan subjek yang sedang diobservasi, sedangkan observasi non partisipatif yaitu apabila pengobservasi tidak ikut terlibat dalam kegiatan subjek yang sedang diobservasi.

Berdasarkan pendapat di atas, metode observasi yang yang digunakan dalam penelitian ini adalah metode observasi partisipatif untuk mengumpul-kan data dengan cara mengamati tentang kinerja perangkat desa dalam penyeleng-garaan pemerintah desa berdasarkan Undang-Undang Nomor 6 Tahun 2014 Tentang Desa.

\section{2) Metode Wawancara}

Metode wawancara adalah sebuah dialog yang dilakukan oleh pewawancara [14]. Pendapat lain mengatakan bahwa metode wawancara adalah suatu teknik pengumpulan data yang dilakuka dengan cara tanya jawab antara penanya atau pewawancara dengan responden/penjawab" [8].

Dari kedua pendapat ahli di atas, dapat disimpulkan bahwa metode wawancara adalah teknik pengumpulan data dengan cara tanya jawab secara langsung, yang dilakukan oleh pewawancara dengan responden untuk memperoleh informasi yang diinginkan.

Jenis wawancara dibedakan menjadi wawancara wawancara terstruktur dan tidak wawancara terstruktur. Wawancara terstruktur adalah wawancara yang dilaksanakan secara terencana dengan berpedoman pada daftar pertanyaan yang telah dipersiapkan sebelumnya [8]. Sedangkan wawancara tidak terstruktur adalah wawancara yang tidak berpedoman pada daftar pertanyaan.

Dari pendapat tersebut, maka dapat bahwa metode wawancara yang digunakan dalam penelitian ini adalah metode wawancara terstruktur yang digunakan untuk mengumpulkan data kinerja dan kendala-kendala perangkat desa dalam 
penyelenggaraan pemerintah desa berdasarkan Undang-Undang Nomor 6 Tahun 2014 Tentang Desa.

3) Metode Dokumentasi

Metode dokumentasi yaitu mencari data mengenai hal-hal atau variabel yang berupa catatan, transkrip, buku, surat kabar, majalah, prasasti, notulen raport, lager agenda dan sebagainya [14]. Metode dokumentasi yang digunakan dalam penelitian ini adalah bentuk catatan tentang desa Gunung Sari yaitu berupa profil desa, nama-nama staf desa dan sebagainya.

\section{Teknik Analisis Data}

Metode analisis data merupakan strategi penelitian untuk memperoleh data yang valid sesuai dengan karatcristik variabel dan tujuan penelitian [15]. Analisis data yang digunakan dalam penelitian ini yaitu analisis deskriptif dengan menggunakan analisis model interaktif. Analisis interaktif terdiri dari tiga alur kegiatan yang terjadi secara bersama yaitu reduksi data, penyajian data dan penarikan kesimpulan, verifikasi [14].

Reduksi data diartikan sebagai pemilihan, pemusatan pada penyeder-hanaan, pengabstrakan dan transformasi data kasar yang muncul dari catatancatatan tertulis dilapangan [14]. Data yang direduksi dalam penelitian ini adalah data tentang tinjauan hukum tentang kinerja perangkat desa dalam penyelenggaraan pemerintah desa berdasarkan Undang-Undang Nomor 6 Tahun 2014 Tentang Desa.

Alur penting yang kedua dari kegiatan analisis data adalah penyajian data sebagai kesimpulan informasi tersusun yang memberikan kemungkinan adanya penarikan kesimpulan dan pengambilan tindakan [14]. Data yang disajikan dalam penelitian ini mengenai tinjauan hukum tentang kinerja perangkat desa dalam penyelenggaraan pemerintah desa berdasarkan UndangUndang Nomor 6 Tahun 2014 Tentang Desa.

\section{HASIL DAN PEMBAHASAN}

\section{Hasil Penelitian}

Dari hasil penelitian terhadap responden terdapat hambatan kepala desa dalam melaksanakan pembangunan dari berbagai indikator penelitian. Dalam hal ini untuk mengcapai tujuan pembangunan harus adanya kerja sama antara masyarakat dengan kapala desa agar semua yang direncanakan kepala desa tercapai, akan tetapi di desa Gunung Sari belum tercapinya perkembangan pembangunan dikarenakan kurangnya partisipasi masyarak. Hambatan yang dilalui kepala desa dalam pelaksanaan pembangunan sebagai berikut:

a) Dalam membuat perencanaan pembangunan desa yang diketahui dari hasil penelitian yaitu:

1) Tidak terkumpulnya data mengenai apa yang di inginkan masyarakat dalam pembangunan.
2) Masyarakat sebagian kecil kurang aktif dalam musyawarah dalam perencanaan pembangunan.

3) Sulitnya menentukan prioritas dalam pelaksanaan pembangunan (Bapak. H. Abdi, Wawancara 22 Mei 2017)

b) Memberikan pengarahan kepada bawahan atau masyarakat dalam pelaksanaan pembangunan adalah:

1) Sulitnya mengumpulkan masyarakat desa untuk diberi pengarahan mengenai pelaksanaan pem-bangunan.

2) Rendahnya pemahaman masyarakat dalam menyerap pengarahan yang disampaikan kepala desa.

3) Masyarakat haya mau berpartisifasi apabila diberi upah atau gaji.

4) Mengambil keputusan dalam proses penyelenggaraan pembangunan (Bapak. Abidin, Wawancara 23 Mei 2017)

c) Sulitnya mengambil keputusan karena banyaknya kebutuhan masyarakat dan kelompok-kelompok masyarakat.

1) Rapat dalam mengambil keputusan sering hanya dihadiri oleh aparat desa dan tokoh masyarakat saja sedangkan masyarakat hanya hadir kadang-kadang.

2) Dalam mengambil keputusan kepala desa seing dihadapkan pada pertentangan antara kelompok masyarakat dan masyarakat banyak (Bapak. Jumaidi, Wawancara 24 Mei 2017)

d) Dalam mengkoordinir penyelenggaraan pembangunan desa adalah:

1) Kurangnya kemampuan kepala desa untuk mengkoordinir tugas-tugas penyelenggaraan pembangunan.

2) Kurang jelasnya pembagian tugas antara aparat desa dengan masyarakat desa.

3) Masyarakat yang diajak dalam pembangunan tidak bisa diajak secara suka rela (Bapak. H. Abdi, Wawancara 25 Mei 2017)

e) Dalam mengawasi aktivitas-aktivitas proses penyelenggaraan pembangunan desa adalah:

1) Kurangnya pengawasan yang dilakukan kepala desa karena jarang datang kelokasi pembangunan.

2) Pelaksanaan pembangunan kurang tepat waktu dalam penyelesaiannya karena banyak penyimpangan yang terjadi dilokasi pembangunan

3) Keterlambatan bahan material dikarenakan cuaca yang kurang mendukung terhadap pelaksanaan pembangunan (Bapak. H. Abdi, Wawancara 26 Mei 2017) 
Dilihat dari hasil penelitian bahwa pembangunan desa, didesa Gunung Sari yang sampai pada saat ini belum telaksana dengan baik dikarenakan antara pemerintah desa dengan masyarakatnya belum bekerja sama . dan kesalahan tidak sepenuhnya dilimpahkan kepada kepala desa justru kerjasamanya yang belum optimal ,karena kesibukan masing-masing tanpa mempertimbangkan kepentingan bersama.

\section{Pembahasan}

Berdasarkan hasil observasi, wawancara, dan dokumentasi bahwa kinerja perangkat desa dalam penyelenggaraan pemerintah desa berdasarkan Undangundang Nomor 6 Tahun 2014 Tentang Desa sudah berjalan secara optimal, hal tersebut terlihat dari kemampuan Dalam Membuat Perenca-naan Pembangunan Desa, kemampuan Dalam Memberikan Pengarahan Kepada Bawahan atau Masyarakat Dalam Pelaksanaan Pembangunan, kemampuan Dalam Mengambil Keputusan Dalam Proses Penyelenggaraan Pembangunan, kemampuan Dalam Mengkoordinir Penyelenggaraan Pembangunan Desa, dan kemampuan Dalam Mengawasi Aktivitas-Aktivitas Dalam Proses Penyelenggaraan Pembangunan Desa.

Pemerintah desa Gunung Sari Kecamatan Gunung Sari Kabupaten Lombok Barat dalam penyelenggaraan pemerintahan yang baik diperlukan kerjasama antara pemimpin dengan pegawainya. Untuk itu para pegawai dituntut agar bertanggung jawab dalam berbagai usaha dalam upaya penyelenggaraan pemerintahan yang baik.

Pada dasarnya kemampuan yang dimiliki oleh pegawai kantor Desa Gunung Sari Kecamatan Gunung Sari Kabupaten Lombok Barat sudah cukup baik dan memadai dalam upaya melaksanakan program-program kerja yang ada dalam ruang lingkup pemerintah Desa Gunung Sari Kecamatan Gunung Sari Kabupaten Lombok Barat. Namun masih terdapat beberapa hal yang masih menjadi catatan tersendiri untuk pemerintah Desa Gunung Sari Kecamatan Gunung Sari Kabupaten Lombok Barat. Hal ini dikarenakan masih adanya beberapa kendala mendasar yang terjadi dalam pelaksanaan program-program kerja yang dikarenakan faktor kemampuan pegawai yang ada dalam ruang lingkup kantor Desa Gunung Sari Kecamatan Gunung Sari Kabupaten Lombok Barat yang mengakibatkan terkendalanya proses penyelenggaraan pemerintahan di Desa Gunung Sari Kecamatan Gunung Sari Kabupaten Lombok Barat.

Begitupula halnya dengan masih perlunya untuk menumbuhkan motivasi kerja bagi para pegawai di kantor Desa Gunung Sari Kecamatan Gunung Sari Kabupaten Lombok Barat. Peneliti menemukan bahwa para pegawai dalam ruang lingkup kantor Desa Gunung Sari Kecamatan Gunung Sari Kabupaten Lombok Barat masih sangat kurang motivasi dalam melakukan pekerjaannya. Hal ini dibuktikan dengan adanya beberapa orang pegawai kantor Desa Gunung Sari Kecamatan Gunung Sari Kabupaten Lombok Barat yang datang terlambat dan pulang lebih cepat dari jam yang telah ditentukan. Padahal motivasi kerja menjadi bagian penting dalam rantai penyelenggaraan pemerintahan yang baik suatu organisasi. Hal ini dikarenakan motivasi akan berpengaruh langsung terhadap hasil dari apa yang telah dikerjakan oleh pegawai tersebut. Kemudian hasil dari kinerja pegawai tersebut akan berpengaruh langsung terhadap keberlangsungan suatu program kerja yang telah disusun sejak awal, Khususnya program kerja di Desa Gunung Sari Kecamatan Gunung Sari Kabupaten Lombok Barat.

Pemberlakuan Undang-undang Nomor 6 Tahun 2014 tentang desa, membawa perubahan struktur pemerintahan Desa Gunung Sari dimana pemerintahan desa diberikan kewenangan untuk mengatur dan menjalankan sendiri urusan rumah tangga desanya, termasuk dalam hal pengelolaan keuangan desa. Pengelolaan keuangan desa perlu dilakukan oleh Kepala Desa.Dengan tetap dilakukan pengawasan oleh BPD dan mengikutsertakan masyarakat.

Pengelolaan keuangan desa dapat dilakukan dengan: Perencanaan APBDes yaitu yang mencakup pendapatan dan belanja, pengumpulan pendapatan desa yang bersumber dari pendapatan asli desa, alokasi anggaran pendapatan dan belanja Negara, bagian dari hasil pajak daerah, alokasi dana dan pendapatan-pendapatan lain desa yang sah.

Alokasi atau pembelanjaan dana APBDes tersebut perlu dikelola dengan beberapa prinsip pengelolaan keuangan desa yang baik yaitu dengan adanya rancangan APBDes yang berbasis pada programprogram, rancangan APBDes yang berdasarkan pada partisipasi masyarakat. Keuangan yang dikelola harus secara bertanggung jawab (akuntabilitas), keterbukaan (transparansi) dan daya tanggap (responsivitas) terhadap prioritas kebutuhan masyarakat.Keberadaan Undang-undang Nomor 6 Tahun 2014 tentang desa membawa perubahan dalam sistem pemerintahan desa, dan telah dirasakan hampir seluruh perangkat desa. Kepala Desa diberi kewenangan penuh untuk mengatur dan membangun desa. Demikian halnya dengan Badan Pemusyawaratan Desa (BPD) mengalami perubahan, jika sebelumnya BPD merupakan unsur penyelenggara pemerintah desa maka dalam Undang-undang Nomor 6 Tahun 2014 tentang desa menjadi lembaga desa. BPD harus menjadi lembaga yang independen. Yang berarti adanya pengawasan dan evaluasi yang dilakukan oleh BPD terhadap pelaksanaan kegiatan yang ditangani oleh pemerintah desa.

Undang-undang Nomor 6 Tahun 2014 tentang desa merupakan Undang-undang yang baru. Pelaksanaan Undang-undang tersebut dalam pelaksanaan pembangunan oleh Kepala Desa di Desa Gunung Sari sudah terlaksana dengan baik. Hal ini dapat dilihat dari pembangunan yang dilaksanakan dengan meningkatkan kesejahteraan masyarakat desa dan kualitas hidup manusia serta penanggulangan sarana dan prasarana 
desa, pengembangan potensi lokal, serta pemanfaatan sumber daya alam dan lingkungan secara berkelanjutan dengan mengacu pada Undang-undang Nomor 6 tahun 2014 tentang desa. Hal ini juga dapat dilihat dari pembangunan-pembangunan yang dilakukan oleh Kepala Desa misalnya membangun jalan onderlah dan pembuatan drainase baru di Desa Gunung Sari. Pemerintah desa perlu terus-menerus dikembangkan sesuai dengan kemajuan masyarakat desa dan lingkungan sekitarnya.

Oleh karena itu, penyelenggaraan pemerintahan desa diharapkan menjadi wadah atau gelanggang politik baru bagi warga desa dan membangun tradisi demokrasi, sekaligus tempat pembuatan kebijakan publik desa. Hal ini bisa terealisasi apabila Kepala Desa, berperan aktif dalam membangun desa bersama perangkat desa dan masyarakat berarti pemerintah desa adalah Kepala Desa sebagai eksekutif. Peran dan fungsi yang telah ditetapkan oleh Undang-undang dan Peraturan Pemerintah menjadikan fungsi Kepala Desa sebagai kepala pemerintahan harus memberi ruang pada partisipasi masyarakat. Pemerintah Desa adalah dalam rangka meningkatkan kuantitas dan kualitas aparatur desa dalam melaksanakan pelayanan masyarakat di Gunung Sari.

\section{SIMPULAN DAN SARAN}

Hasil penelitian menunjukkan bahwa 1) Kinerja perangkat desa dalam penyelenggaraan pemerintah desa berdasarkan Undang-Undang Nomor 6 Tahun 2014 Tentang Desa sudah berjalan secara optimal, hal tersebut terlihat dari kemampuan Dalam Membuat Perencanaan Pembangunan Desa, kemampuan Dalam Memberikan Pengarahan Kepada Bawahan atau Masyarakat Dalam Pelaksanaan Pembangunan, kemampuan Dalam Mengambil Keputusan Dalam Proses Penyelenggaraan Pem-bangunan, kemampuan Dalam Mengkoordinir Penyelenggaraan Pembangunan Desa, dan kemampuan Dalam Mengawasi Aktivitas-Aktivitas Dalam Proses Penyelenggaraan Pembangunan Desa. 2) Kendala-kendala tentang kinerja perangkat desa dalam penyeleng-garaan pemerintah di Desa Gunung Sari Kecamatan Gunung Sari Kabupaten Lombok Barat Tahun 2017yaitu a) Persoalan Sumber Daya Manusia b) Fenomena pengalaman sistem pembangunan dari masa orde baru hingga masa reformasi saat ini masih kuat di memori masyarakat desa. c) Hilangnya kepercayaan masyarakat desa atas pengalaman umum adanya kasus korupsi serta merosotnya moralitas pemimpin atas komitmen transparansi dalam pelanyanan publik. d) Adanya sistem pembangunan yang selama ini masih terkesan topdown dan lebih di dominasi oleh elite desa, walaupun banyak pihak yang mengatakan reformasi telah merubah tatanan pemerintahan tetapi dilevel desa khususnya desa-desa yang sangat jauh dari kondisi perkotaan, masih sangat nampak. e) Kewenangan yang diberikan kepada desa melalui Undang-undang Nomor 6 tahun 2014 tentang desa memicu persoalan baru. Misalkan dalam Undang-undang Nomor 6 tahun 2014 tentang desa telah meberi penguatan kepada BPD dalam melakukan pengawasan tetapi BPD hanya membahas dan menerima laporan dari masyarakat serta mengawasi kinerja pemerintah desa. Artinya keterlibatan BPD terbatas dan kurang mendetail dalam Undang-undang Nomor 6 Tahun 2014 tentang desa akan mengurangi kontrol dari masyarakat melalui wakilnya di BPD. 94 f) Masa jabatan Kepala Desa selama 6 tahun dan selama tiga periode. Lamanya masa jabatan ini baik secara berturut-turut maupun tidak akan membuka ruang yang memungkinkan terjadinyakewenangan. g) Badan pemusyawaratan Desa (BPD) adalah suatu lembaga yang memproduk hukum dan Peraturab Desa tetapi dalam hal tata cara pengambilan keputusan belum maksimal, karena sumber daya manusia dan secara teknis masih sangat membutuhkan pembinaan dan pelatihan dari Pemerintah Kabupaten. Kesejahteraan anggita BPD belum menjadi prioritas Pemerintah Kabupaten. h) Lembaga Pember-dayaan Massyarakat (LPM) adalah lembaga yang terkait di bidang perencanaan pembangunan yang ada di desa tetapi tata cara penggalian gagasan dan perencanaan kegiatan masih sangat perlu pembinaan dan bimbingan teknis dari Pemerintah Kabupaten.

Disarankan kepada Pemerintah Desa Gunung Sari Kecamatan Gunung Sari Kabupaten Lombok Barat agar menjabarkan dengan jelas tentang Kewenangan Desa berdasarkan asal-usul dan adat istiadat masyarakat setempat dengan memahami potensi desa serta warisan adatnya yang masih hidup dikaitkan dengan pelaksanaan kewenangannya dan kepada Pemerintah Desa Gunung Sari Kecamatan Gunung Sari Kabupaten Lombok Barat untuk membuat dan melengkapi produk legislasi terkait pelaksanaan kewenangan desa sehingga Pemerintah Desa dalam menjalankan roda pemerintahan berada pada pijakan peraturan perundang-undangan yang jelas.

\section{UCAPAN TERIMA KASIH}

Penulis mengucapkan terima kasih kepada editor yang senantiasa memberikan saran dan masukan kepada penulis sehingga artikel ilimiah ini selesai dengan baik.

\section{DAFTAR RUJUKAN}

[1] R. Indonesia, "Undang-undang Nomor 6 tahun 2014 tentang Desa," 6AD.

[2] U. N. Anonim, "Undang-Undang Nomor 32 Tahun 2004 Tentang Pemerintah Daerah," Dewan Perwakilan Rakyat, 2005.

[3] P. P. R. Indonesia, "Peraturan Pemerintah Republik Indonesia Nomor 43 Tahun 2014 tentang Peraturan Pelaksaan Undang-undang Nomor 6 Tahun 2014 Tentang Desa," Jakarta Sekr. Negara, 2014. 
[4] R. Bintaro, "dalam Muharomi, 2009," Sikripsi Perubahan Status Kepemilikan Lahan Pertan. Terhadap Kondisi Sos. Ekon. Masy. Petani Desa UNPAD.

[5] T. V. Yustisia, Undang-Undang Nomor 6 Tahun 2014 Tentang Desa dan Peraturan Terkait. Visimedia, 2015.

[6] E. Sutoro and T. Kashanah, "Desa Membangun Indonesia," in Forum Pengembangan Pembaharuan Desa (FPPD) Yogyakarta, 2014.

[7] Sugiyono, Metode Penelitian Pendidikan:(Pendekatan Kuantitatif, Kualitatif dan $R \& D$ ). Alfabeta, 2014.

[8] Sukardi, "Metodologi Penelitian Pendidikan (Kompetensi dan Prakteknya)," Jakarta Bumi Aksara, 2005.

[9] A. Suharsimi, "Dasar-dasar Evaluasi Pendidikan Edisi 2," Jakarta PT Bumi Aksara, 2013.

[10] Mardalis, "Metode Penelitian (Suatu Pendekatan Proposal)," Cet. VIII. Bumi Aksara. Jakarta, 2006.

[11] S. Winarno, "Pengantar Penelitian Ilmiah Metode dan Teknik," Bandung: Tarsito, 2008.

[12] M. dkk Subana, "Dasar-dasar Penelitian Ilmiah." Bandung: Pustaka Setia, 2005.

[13] N. dkk. Sudjana, "Penelitian dan Penilaian Pendidikan," 2007.

[14] A. Suharsimi, "Prosedur Penelitian, Jakarta: PT," Rineka Cipta, 2013.

[15] D. Ary, C. J. Luchy, and R. Ashgar, "Pengantar Penelitian dalam Pendidikan diterjemahkan oleh Arief Furchan 2007," Yogyakarta: Pustaka Pelajar, 1982. 